\title{
An Overview of Current Scenario of Sericulture Industry in Jammu and Kashmir, India
}

\author{
Muzafar Ahmad Bhat', Zafar Iqbal Buhroo², Abdul Aziz ${ }^{1}$, \\ Jasmeena Qadir ${ }^{3}$ and M. Azam ${ }^{4}$
}

${ }^{1}$ P. G. Department of Sericulture, Poonch Campus, University of Jammu, Jammu \& Kashmir, 185101, India.

${ }^{2}$ Temperate Sericulture Research Institute, Sher-e-Kashmir University of Agricultural

Sciences and Technology of Kashmir-Mirgund, Jammu \& Kashmir,193121, India.

${ }^{3}$ Division of Sericulture, Sher-e- Kashmir University of Agricultural Sciences and Technology

of Jammu, Chatha, India -180009.

${ }^{4}$ Department of Zoology, Govt. Degree College Poonch, University of Jammu, Jammu \& Kashmir, 185101, India

*Corresponding author

\section{A B S T R A C T}

\begin{tabular}{l} 
Ke yw o r d s \\
Cocoon, \\
$\begin{array}{l}\text { Economics, } \\
\text { Rearers, Silkworm }\end{array}$ \\
\hline Article Info \\
\hline $\begin{array}{l}\text { Accepted: } \\
\text { 26 May } 2020 \\
\text { Available Online: } \\
\text { 10 June } 2020\end{array}$ \\
\hline
\end{tabular}

Sericulture as an industrial sector has been a component of the backbone of Jammu \&Kashmir state's economy, carrying itself, a rich history. The prevailing climate and availability of skilled labour in the valley of Kashmir are the favourable factors existing for silk production. There are 2,800 villages and 33,000 households which have taken up sericulture as an important economic activity. In the state, there are about 7 lakh mulberry trees, out of which 53 per cent $(370,000)$ are in Jammu division and 47 per cent in Kashmir division. Annually, about 1022 MT of cocoon are produced generating an income of about Rs. 2224 lakh for these silkworm rearers coupled with the annual employment generation to the tune of 3.5 lakh mandays (3.0 lakh on-farm and 0.50 lakh off-farm).The department has 173 mulberry nurseries spread over an area of 963 acres, and 374 mulberry blocks over an area of 2215 acres across the state of Jammu and Kashmir. Annually, about 6,680 quintals of raw silk is produced which is approximately worth Rs. 50 crores or 50 million. However, it is high time to notice that silk production in Jammu \& Kashmir has declined considerably over the past few decades. This study has focused to understand the key challenges faced by the cluster and prepared a strategic action plan to address the issues.

\section{Introduction}

Sericulture as an enterprise has been playing a vital role in sustaining Jammu \& Kashmir (J\&K) state's economy. There is great deal of evidence in ancient Sanskrit literature that the original home of silk is Kashmir. Mirza Muhammad Haider in his 'Tarikhi Rashide' has a mention of mulberry trees (cultivated for their leaves for production of silk) as 
among the wonders of Kashmir. The great king of Kashmir Sultan Zain-ulAbideen who is maker of industrial Kashmir gave special attention to this industry by introducing better techniques. Official reports reveal that Europe was the first continent with which Kashmir had started its silk trade. The reports show that in the year 1855, Kashmir was in a position to supply $25000 \mathrm{oz}$ of silkworm seeds to Europe. By exporting silkworm seeds to Europe, the silk industry of Kashmir gained a pivotal position on the silk route of Europe (Baqual, 1995). When the history of sericulture in Jammu \& Kashmir state is traced, it's seen that the silk industry was demonopolised in 1988. About 33,000 farming families produce around 1022MT of cocoons worth Rs.5.50 crore. An increase to around 1,500 MT is planned in the next decade. Constraints faced and remedial measures suggested are discussed, beginning with the mono cropping pattern. Productivity and quality need to be improved through better packages of mulberry cultivation and silkworm rearing, and high yielding as well as superior quality silkworm breeds. Unmanaged mulberry plantations are to be revived with the required inputs. Lack of rearing space and start up tools for farmers are another factor. Low adoption of improved technologies was observed and hence stressed the dire need of awareness and training programmes. Productivity of silkworm races is a concern, with sericulture being predominantly bivoltine and the majority of cocoon production coming from the spring crop. An autumn crop has been introduced but yield and quality was observed not good. In this connection, a few recommendations were made for mulberry leaf production, cocoon production, and post-cocoon management. Besides these, suggestions were made for overall improvements in the industry (Bhat, 2014). It is a known fact that the mulberry silkworm reared in the state of Jammu and Kashmir produces superior quality of cocoon in the continent Asia. It yields a very fine fiber that stands at par with the best in the world. In the state, mulberry trees exist even in the wild form of antiquity. In Kashmiri language, the silk-fibre is known as 'pote' and the silkworm is the potikeom (insects).

Kashmir, famous for its silk across the globe, currently produces 800 MT of cocoons besides generating employment of four lakh man-days annually. Approximately, 22, 000 farmers are engaged directly or indirectly with the industry presently (Bilal, 2010). Inadequacy of mulberry leaves and damage caused by insects and pests are the major problems in the development and expansion of sericulture. Now the sericulture development department is laying stress on raising dwarf mulberry trees to supplement and replenish the traditional tall mulberry trees. As a result of these efforts, the dwarf varieties have increased substantially in the state, a temporal change in the sericulture development, the total number of mulberry trees in the state was 219,500 out of which 82,600 trees belonged to the Jammu division and 136,900 in the Kashmir division. The number of mulberry trees in the state increased to $1,668,000$ in 1990-91 and recorded a marginal increase on this number in 1994-95, the total number being $1,685,000$ (Farooq and Nisar, 2011).

\section{Demand side analysis of sericulture for Jammu and Kashmir}

Silk textile is one of the most ancient industries of Jammu and Kashmir. Kashmiri silk goods are renowned for their quality, colour and shades, the world over. There are historical evidences which prove that silk fabrics used to be exported to Persian, Greek and Roman empires. During the medieval period, the Mughals were the great lovers of silken clothes. They patronized this industry in the valley of Kashmir (Directorate of 
Economics and Statistics, 2017). Sericulture still continues to be subsidiary occupation for about 30000 rural families in the state. Most of these families belong to economically backward sections of the society. The nurseries are utilized for production of saplings/cuttings for further distribution among farmers to augment area under mulberry and mulberry blocks which serve as leaf reservoirs for the landless and marginal farmers. Annually, about 20.00 lakh plants are produced from these nurseries against the potential of 30.00 lakh plants. The department has well established seed organization and presently, about $60 \%$ of local annual seed demand is met out from within the sector (Economic Survey, 2010-11).

There are approximately, 0.38 lakh weavers in the state who are engaged in this industry under organized and unorganized sectors. Moreover, the handloom goods have great demand in the national and international markets. There are 3741 handloom units in the state employing same number of persons producing loies, puttos, tweed, blankets, raffals, pashmina and dusotikhad (Economic survey, Jammu and Kashmir, 2014-15).

The Rajbagh silk factory is engaged in manufacturing of silk fabrics out of silk yarns which is being supplied by the two filatures of $\mathrm{J} \& \mathrm{~K}$ at Srinagar and Jammu. It has been engaged for the last seventeen years in the manufacturing of high quality silk fabrics. There are mainly two types of silk products delivered by the factory (Nisar and Afifa, 2012), these are:

\section{Twisted silk products}

These include crap, chinon, chiffon and georgette. All these varieties are made up of $100 \%$ pure silk. The difference however lies in the weaving and weight of silk yarns used, giving a unique feature to each variety. For instance, while weaving, crap and chinon are given right angled twist whereas, chiffon and georgette are given counter clockwise twist, giving former a smooth shiny and latter, a wrinkled appearance. Besides this, the difference in the weight of silk yarns used also determines their quality as shown below:

\begin{tabular}{|l|l|}
\hline Variety & $\begin{array}{l}\text { Weight of silk } \\
\text { per meter }(\mathrm{g})\end{array}$ \\
\hline Crap & $60-80$ \\
\hline Chinon & 40 \\
\hline Chiffon & 40 \\
\hline Georgette 20 \\
\hline
\end{tabular}

\section{Un-twisted silk products}

These include varieties like champion, habuti and satin. Here, all these varieties are given a simple weaving without any twist, giving them a natural shine. Like twisted silk products, these also differ in the weight of silk yarn used while weaving. The names of all these varieties of silk have been derived from China, the place of its origin and the differences in weight are as follows:

\begin{tabular}{|c|c|}
\hline Variety & $\begin{array}{c}\text { Weight of silk per meter } \\
(\mathrm{g})\end{array}$ \\
\hline Champion & 20 \\
\hline Habuti & 40 \\
\hline Satin & 120 \\
\hline
\end{tabular}

Supply-side analysis of sericulture in Jammu and Kashmir

Jammu and Kashmir is the only state of the country which lies at the same altitude with that of the leading bivoltine sericulture countries of the world. It is having a climate edge over the other sericulture states of the country in production of bivoltine silk. Even the sericulture experts of Japan have recognized the superiority of natural climatic conditions in the state as favourable for the development of sericulture and for the 
production of high grade raw silk of international standard. The bivoltine sericulture development has been one of the priority sectors of Indian silk industry and its production is yet to meet the target. Although India is the second largest producer of silk in the world, against the current domestic demand of 25000 MT of silk, considering all varieties, India produces only about 17000 MT of raw silk, while the rest is being imported from other countries mostly from Republic of China. The production of quality bivoltine silk is still a challenge. The Jammu and Kashmir is the only state in India having enormous potential to produce bivoltine silk of international grade which can help to reduce the import of bivoltine silk in the country (Hussain, 2002). There are two supplementary silk reeling units in Jammu and Kashmir, namely government silk filatures Rajbagh, Srinagar in Kashmir division and another government silk factory, Jammu in Jammu division (Afifa, 2000).

Kashmir reeled silk has its luster and is famous throughout the world as it has more fiber length as compared to spun silk. The increased length of the fiber makes the product more durable than short length fibers do. All we need to have is the 'growers' to raise mulberry trees to rear cocoons which can give a new boost to this industry. The state has potential to produce and consume raw silk locally and thus establish a strong backward linkage for many other industries which can rejuvenate our industrial sector. It is fortunate that we have the distinction to produce good quality carpets and our carpet manufacturing enjoys its reputation the world over. The promotion of silk industry finds its favour as the silk reeled in Kashmir can be marketed here as a raw material for our carpet industry and we need not import spun silk which is nothing but wastage of reeled silk and is less durable. The silken carpets which are otherwise in great demand in the international market can yet touch new heights on the scale of customer satisfaction if we use reeled silk from Kashmir and this can contribute substantially to the export kitty of the state. Our carpets made with locally reeled silk can be of higher quality with distinctiveness as Kashmir specific and can qualify for registration under geographical indications act. This step shall help us to create a brand image of our product and we can tap the yet untapped national and international markets and also increase our share in the markets we operate in at present.

The Indian Institute of Carpet Technology (IICT), Srinagar after immense hard work in the area of R\&D has already come up with a silken carpet which is made of reeled mulberry silk produced in Kashmir and the material has been put to thorough testing before its actual use. Kashmir reeled mulberry silk is far superior to the spun silk which is made of the wastage of reeled silk. The innovative carpet which is first of its kind in the history of carpet industry has the added advantage of losing negligible pile at the time of washing and is more durable than the one made of spun silk. It also does not involve use of chemicals for shining but, has natural shine. It requires less quantity of raw material by $7-8 \%$, for making the carpet with this type of silk as compared to carpet made with spun silk. This high premium product has the features to be at par with the high quality carpets from Iran and China. As a matter of fact, the project undertaken by IICT, Srinagar to develop reeled silken carpet has been in view of the fact that other prime competitors like Iran and China are using reeled mulberry silk for carpets as the raw material and thus provides them an edge over the carpets made from spun silk. Although a few carpet manufacturers have already evinced interest in adopting the innovation, the introduction of this product in the market is in the stage of infancy. The move is likely to rejuvenate a 
new life in our silk industry which has suffered a lot over the past few decades. It will provide import substitution for the raw material used in manufacture of silken carpets at present and thus help in our balance of trade. The need of the hour is to lure more and more unemployed educated youth towards this sector by giving them incentives and facilities to start their enterprises in sericulture. The Kashmir carpet industry which contributes $50-60 \%$ of the total value of handicrafts sector with its annual turnover of around Rs.1000 crores during the year 2007-08 can flourish and touch new peaks of growth by getting a strong backward integration. A convergent approach would be appreciable to address the problems of silk industry by organizations viz., SKUAST (Jammu and Kashmir), State Sericulture Department and Central Sericultural Research and Training Institute, Central Silk Board, to improve the quality of the cocoons as high yielding variety ones can help to reduce the price of reeled silk yarn to give a new impetus to the industry by revival of defunct silk units/ factories and establishment of new ones which can restore its past glory (Kaneez, 2018).

The raw silk produced by the filatures forms the basic raw material for the weaving segment of the silk industry. Kashmir filatures sell their raw silk mainly to Rajbagh silk factory and hand loom weaving factory except for a small portion being sold to private unit holders on the basis of quota. There are 126 power looms and 170 handlooms engaged in silk weaving in the public sector in Kashmir. Power looms are located at the silk weaving factory, Rajbagh, which has been under the control and management of Jammu and Kashmir Industries Corporation. Handlooms are centralized at handloom silk weaving factory, Badamibagh which was also under the control and management of Jammu and Kashmir
Industries Corporation up to 1992, in the year 1992, handlooms weaving factory was transferred to Jammu and Kashmir handloom development corporation. Besides providing large volume of indirect employment, Rajbagh factory and handlooms factory directly employs 1500 and 1700 personnel, respectively. It's a matter of great concern to notice that there has been a continuous decreasing trend in the volume of production in both the organizations, particularly in the case of Rajbagh factory. There are also a few private reeling units in the state (Nisar et al., 2012) (Table 1-8).

\section{Employment and income generation from sericulture industry in Jammu and Kashmir}

The government of Jammu and Kashmir is committed to boost the sericulture industry for the benefit of cocoon growers and generate employment for the youth. Since Kashmiri cocoons are famous due to its purity, people from across the world prefer to purchase silk products from the valley. The government has already announced several small schemes, including free planting material and distributing free rearing kits that growers are using during silkworm rearing process. Recently, sericulture authorities organized a cocoon auction market, where growers sold their cocoons to local and outside merchants who came from different parts of the country including West Bengal, Karnataka and Bhopal (Ganie et al., 2018).

Sericulture being an agro based industry, has been considered as an excellent sector for generation of employment both in rural and urban areas, through a series of activities, such as raising and planting of mulberry plants, silkworm rearing, production of silkworm seed, reeling of silk cocoons, making of silk fabric, printing, dyeing and finished product making and their marketing. 
Besides this, raising of mulberry plantation is environment friendly and serve the purpose of social forestry. In the XII five year plan, a target of approximately 68 lakh man days is expected to be generated through various onfarm and off-farm sericulture activities. However, due to globalization of trade, sericulture sector has received set back in recent years due to import of silk yarn mainly from China against comparatively lower prices. In the process of minimizing production cost, sericulture farmers who are mainly marginal ones and other stakeholders try to adopt short cuts which are telling upon average production of sericulture activities. Sericulture farmers in our state are not able to en-cash their produce as per their timely need and at times, against profitable return, but have to wait for organizing of cocoon auction market by the Department once in an year, being a mono-crop producing state.

Silk industry in the state has a glorious past and provided employment opportunity to almost half of the population of the state. In due course of time, due to evolving of other allied sectors like Agriculture, Horticulture etc., the sericulture sector received less attention and was pushed back in terms of development. Due to concerted efforts of the Department, around 30,000 families are involved in silkworm rearing activity at present and the crop production in the state is showing an increasing trend. Presently, only 20 to $30 \%$ of the production of raw silk cocoons of the state is consumed within the state, while the rest of the cocoon material goes outside the state through buyers from Bengal and Karnataka. Despite purchase of silk cocoon material by outside buyers, marketing of silk cocoons has been one of the hurdles in the way of fast development of silk industry in the state. Trade globalization and import of silk yarn from China against comparatively lower rates have added to the hardships of the industry. The sericulture activity is able to provide livelihood earnings, starting from an unskilled individual to skilled one during the course of raising and maintenance of the mulberry wealth, silkworm rearing and the finished product making during its value addition process (Directorate of Economics and Statistics, 2017) (Table 9 and 10).

\section{Income generation from sericulture in Jammu and Kashmir}

Sericulture and silk production have an enormous potential in the state of Jammu and Kashmir provided- it is made available to rural people, especially to women, and its marketing is organized independently. It can serve as an excellent mode for employment generation and augmentation of income. This requires providing not only fresh technology inputs to primary producers but more importantly, evolving and establishing new systems of organized production and marketing (Singh and Andrabi, 2019).

\section{Other aspects of sericulture in Jammu and Kashmir}

Jammu and Kashmir is strategically and geopolitically a sensitive state. The state government with financial support of the government of India envisaged inter-alia, to improve necessary infrastructure for enhancing the productive capacity of the state to make it self-sufficient. A number of ambitious flagship programmes have been launched by adopting synchronized approach which enrich the economy and narrow down the rural-urban gap by spreading growth benefits uniformly (Farhat et al., 2010).

Strength, weakness, opportunities and threats (SWOT) analysis

SWOT analysis is a strategic planning method used to evaluate the strengths, weaknesses, 
opportunities and threats involved in any venture. SWOT also encompasses a comprehensive analysis of the development parameters linked with economic performance of the state thereby enabling the policy makers and researchers to reorient themselves to the prevailing conditions (Economic survey, Jammu and Kashmir 2013-14, 2014-15). The highlights of SWOT analysis of the socio-economic fabric of the state are as follows.

Table.1

\begin{tabular}{|c|c|}
\hline Strength & Weakness \\
\hline Traditional nature of sericulture. & $\begin{array}{l}\text { Scarcity of improved and } \\
\text { abundant mulberry wealth. }\end{array}$ \\
\hline $\begin{array}{l}\text { Well organized base and } \\
\text { emotional attachment of the } \\
\text { people with it. }\end{array}$ & $\begin{array}{l}\text { By and large mono- } \\
\text { cropping system. }\end{array}$ \\
\hline $\begin{array}{l}\text { Congenial conditions for spring } \\
\text { and autumn rearing. }\end{array}$ & $\begin{array}{l}\text { Non availability of required } \\
\text { rearing space. }\end{array}$ \\
\hline $\begin{array}{l}\text { Low industrialization leading to } \\
\text { pollution free environment and scope } \\
\text { for sericulture development. }\end{array}$ & $\begin{array}{l}\text { Unscientific approach of } \\
\text { rearers towards certain } \\
\text { technicalities like disinfection } \\
\text { and rearing hygiene. }\end{array}$ \\
\hline $\begin{array}{l}\text { Rich heritage of traditional } \\
\text { designs adaptable to changing } \\
\text { fashions. }\end{array}$ & $\begin{array}{l}\text { Poor extension system and } \\
\text { inadequate market linkage. }\end{array}$ \\
\hline Opportunities & Threats \\
\hline $\begin{array}{l}\text { Marketing, rearing and weaving } \\
\text { linkages of the produce. }\end{array}$ & $\begin{array}{l}\text { Poor infrastructure and } \\
\text { poor availability of } \\
\text { quality foliage. }\end{array}$ \\
\hline $\begin{array}{l}\text { Availability of good research } \\
\text { support. }\end{array}$ & $\begin{array}{l}\text { Traditional adherence of } \\
\text { farmers towards old } \\
\text { practices. }\end{array}$ \\
\hline $\begin{array}{l}\text { Sericulture is in the priority list of } \\
\text { the state government. }\end{array}$ & Fluctuation in cocoon prices. \\
\hline $\begin{array}{l}\text { Active support from Department of } \\
\text { Sericulture. }\end{array}$ & $\begin{array}{l}\text { Decentralized nature } \\
\text { of the industry } \\
\text { inhibiting financial } \\
\text { support from financial } \\
\text { institutions. }\end{array}$ \\
\hline \multicolumn{2}{|l|}{$\begin{array}{l}\text { Large scale commercialization of } \\
\text { second crop during autumn season. }\end{array}$} \\
\hline $\begin{array}{l}\text { Improvement of mulberry foliage by } \\
\text { planting high yielding mulberry } \\
\text { varieties }\end{array}$ & \\
\hline
\end{tabular}

Source: Economic survey, Jammu and Kashmir 2013-14, 2014-15, 2015-2016, 2016-2017. 
Table.2 Annual production of silk weaving factory, Rajbagh

\begin{tabular}{|c|c|c|}
\hline Period & $\begin{array}{c}\text { Quantity of silk } \\
\text { (meters in lakhs) }\end{array}$ & $\begin{array}{c}\text { Value } \\
\text { (Rs in lakhs) }\end{array}$ \\
\hline $\mathbf{2 0 0 5 - 0 6}$ & 75000 & 164.683 \\
\hline $\mathbf{2 0 0 6 - 0 7}$ & 74000 & 196.84 \\
\hline $\mathbf{2 0 0 7 - 0 8}$ & 78000 & 226.9 \\
\hline $\mathbf{2 0 0 8 - 0 9}$ & 64100 & 182.085 \\
\hline $\mathbf{2 0 0 9}-10$ & 52500 & 137.26 \\
\hline $\mathbf{2 0 1 0}-11$ & 52500 & 160.925 \\
\hline $\mathbf{2 0 1 1}-12$ & 27300 & 89.216 \\
\hline $\mathbf{2 0 1 2}-13$ & 54500 & 171.675 \\
\hline $\mathbf{2 0 1 3}-14$ & 64100 & 182.085 \\
\hline $\mathbf{2 0 1 4}-15$ & 39500 & 208.56 \\
\hline $\mathbf{2 0 1 5}-16$ & 42500 & 220.15 \\
\hline $\mathbf{2 0 1 6}-17$ & 23600 & 100.064 \\
\hline
\end{tabular}

Source: Rajbagh silk factory, Srinagar, Jammu and Kashmir

Table.3 Sales achieved by silk weaving factory, Rajbagh

\begin{tabular}{|c|c|c|}
\hline Period & $\begin{array}{c}\text { Quantity } \\
\text { produced? (meters } \\
\text { in lakhs) }\end{array}$ & $\begin{array}{c}\text { Value } \\
\text { (Rs in lakhs) }\end{array}$ \\
\hline $\mathbf{2 0 0 5 - 0 6}$ & 0.934 & 110.070 \\
\hline $\mathbf{2 0 0 6 - 0 7}$ & 0.869 & 113.250 \\
\hline $\mathbf{2 0 0 7 - 0 8}$ & 0.937 & 129.950 \\
\hline $\mathbf{2 0 0 8 - 0 9}$ & 0.410 & 182.05 \\
\hline $\mathbf{2 0 0 9}-10$ & 0.509 & 89.080 \\
\hline $\mathbf{2 0 1 0}-11$ & 0.321 & 51.897 \\
\hline $\mathbf{2 0 1 1}-12$ & 0.301 & 51.158 \\
\hline $\mathbf{2 0 1 2}-13$ & 0.360 & 69.800 \\
\hline $\mathbf{2 0 1 3}-14$ & 0.410 & 86.463 \\
\hline $\mathbf{2 0 1 4}-15$ & 0.308 & 66.474 \\
\hline $\mathbf{2 0 1 5}-16$ & 0.351 & 68.715 \\
\hline
\end{tabular}

Source: Rajbagh silk factory, Srinagar, Jammu and Kashmir

Table.4 Present status of sericulture in the State

\begin{tabular}{|l|c|}
\hline Mulberry sector & 173 \\
\hline Departmental nurseries (No.) & 963 \\
\hline Total area of nurseries (acres) & 30 \\
\hline Production capacity of saplings / year (Lakh) & 15 \\
\hline $\begin{array}{l}\text { Present annual sapling production in } \\
\text { Departmental nurseries (Lakh) }\end{array}$ & 110 \\
\hline $\begin{array}{l}\text { Total available mulberry wealth in the state } \\
\text { (Lakh trees) }\end{array}$ & \\
\hline
\end{tabular}




\begin{tabular}{|l|l|}
\hline Seed sector & \\
\hline Grainages (No.) & 6 \\
\hline Basic seed stations (No.) & 9 \\
\hline $\begin{array}{l}\text { Annual Disease Free Layings } \\
\text { production(Lakh) }\end{array}$ & 17 \\
\hline $\begin{array}{l}\text { Annual Disease Free Layings } \\
\text { consumption (Lakh) }\end{array}$ & 29 \\
\hline
\end{tabular}

\begin{tabular}{|l|l|}
\hline $\begin{array}{l}\text { Commercial silkworm } \\
\text { rearing }\end{array}$ & \\
\hline Rearers (No.) & 29400 \\
\hline Sericulture villages (No.) & 2800 \\
\hline $\begin{array}{l}\text { Annual cocoon production } \\
\text { (MT) }\end{array}$ & 1105 \\
\hline Income generation (Lakh) & 2226 \\
\hline
\end{tabular}

\begin{tabular}{|l|l|}
\hline Post cocoon sector & \\
\hline $\begin{array}{l}\text { Rearing units } \\
\text { (No.) }\end{array}$ & 37 (14 functional) \\
\hline
\end{tabular}

Source: Annual Report, Sericulture Development Department, Jammu and Kashmir, 2016-17

Table.5 Cocoon production during the last few years

\begin{tabular}{|c|c|c|}
\hline Period & $\begin{array}{c}\text { Cocoon } \\
\text { production } \\
\text { (MT) }\end{array}$ & $\begin{array}{c}\text { Productivity } \\
\text { per oz (kg) }\end{array}$ \\
\hline $\mathbf{2 0 1 0 - 1 1}$ & 810 & 31.00 \\
\hline $\mathbf{2 0 1 1 - 1 2}$ & 860 & 32.00 \\
\hline $\mathbf{2 0 1 2 - 1 3}$ & 917 & 33.00 \\
\hline $\mathbf{2 0 1 3 - 1 4}$ & 901 & 32.00 \\
\hline $\mathbf{2 0 1 4 - 1 5}$ & 1022 & 34.00 \\
\hline $\mathbf{2 0 1 5}-16$ & 1105 & 42.00 \\
\hline
\end{tabular}

Source: Annual Report, Sericulture Development Department Jammu and Kashmir-2016-17

Table.6 Average price for 'A' grade cocoons (Rs.)

\begin{tabular}{|c|c|}
\hline Year & $\begin{array}{c}\text { Average price } \\
\text { for 'A' grade } \\
\text { cocoons (Rs.) }\end{array}$ \\
\hline $\mathbf{2 0 1 0 - 1 1}$ & 300.00 \\
\hline $\mathbf{2 0 1 1 - 1 2}$ & 410.00 \\
\hline $\mathbf{2 0 1 2 - 1 3}$ & 350.00 \\
\hline $\mathbf{2 0 1 3 - 1 4}$ & 397.00 \\
\hline $\mathbf{2 0 1 4 - 1 5}$ & 650.00 \\
\hline $\mathbf{2 0 1 5 - 1 6}$ & 750.00 \\
\hline
\end{tabular}

Source: Annual Report, Sericulture Development Department, Jammu and Kashmir, 2016-17 
Table.7 Number of private reeling units in Jammu and Kashmir

\begin{tabular}{|c|c|}
\hline Year & Private reeling units (No.) \\
\hline $2010-11$ & 10 \\
\hline $2011-12$ & 22 \\
\hline $2012-13$ & 30 \\
\hline $2013-14$ & 31 \\
\hline $2014-15$ & 34 \\
\hline $2015-16$ & 35 \\
\hline
\end{tabular}

Source: Economic Survey 2015-16, Govt. of Jammu and Kashmir.

Table.8 Raw silk production in Jammu and Kashmir

\begin{tabular}{|r|c|}
\hline Year & Raw silk production (MT) \\
\hline $2010-11$ & 115 \\
\hline $2011-12$ & 120 \\
\hline $2012-13$ & 136 \\
\hline $2013-14$ & 148 \\
\hline $2014-15$ & 152 \\
\hline $2015-16$ & 177 \\
\hline
\end{tabular}

Table.9 Employment from sericulture industry in Jammu and Kashmir

\begin{tabular}{|l|l|}
\hline Period & \multicolumn{1}{|c|}{ No. of persons } \\
\hline $2010-11$ & 75000 \\
\hline $2011-12$ & 1,00000 \\
\hline $2012-13$ & 1,75000 \\
\hline $2013-14$ & 2,25000 \\
\hline $2014-15$ & 3,00000 \\
\hline $2015-16$ & 3,50000 \\
\hline
\end{tabular}

Table.10 Income generation from sericulture sector in Jammu and Kashmir

\begin{tabular}{|r|l|}
\hline \multicolumn{1}{|r|}{ Year } & Income (LakhRs.) \\
\hline $2010-11$ & 800 \\
\hline $2011-12$ & 1100 \\
\hline $2012-13$ & 963.00 \\
\hline $2013-14$ & 1193.00 \\
\hline $2014-15$ & 2026.00 \\
\hline $2015-16$ & 2226.00 \\
\hline
\end{tabular}

Source: Annual Report, Sericulture Development Department, Jammu and Kashmir, 2016-17 Source: Economic Survey 2015-16, Govt. of Jammu and Kashmir

The suitable climate and availability of skilled labour in the valley of Kashmir are the favourable factors for silk production. New study-hybrid species of silkworm need to be developed which can withstand the adverse climatic conditions. Such species of worms enhance the quantity and quality of raw silk. There are 2,800 villages and 33,000 households in which sericulture has become an important economic activity. Out of these, 
1500 villages are situated in the Kashmir division and the remaining 1300 villages in the Jammu division. Sericulture, the technique of silk production, is an agro-industry, which has played an eminent role in the rural economy of Jammu \& Kashmir state. In India, mulberry silk is produced extensively in the states of Karnataka, West Bengal and Jammu and Kashmir. Jammu and Kashmir, owing to its healthy climate during autumn and spring, is producing silk by rearing univoltine silkworms. The valley of Kashmir has the blessing of having been favoured by the nature with a climate and altitude highly conducive for mulberry-culture as such suitable for the advancement of sericulture. These are the factors which further added strength to the belief that Kashmiris had the knowledge of rearing, reeling and weaving of silk much earlier than the Chinese and Tibetans knew it. In fact, the knowledge of sericulture in the Jammu and Kashmir state dates back to very old time which is evident from the reference available in the superb works of a number of travellers who visited this state in the past. But, owing to the monopoly of government and turmoil like conditions in the state for the past three to four decades in fact, in the past five decades, the silk production of the state has dwindled by fifty percent which means that on an average, every year we have been losing $1 \%$ of silk production. As per different estimates and reports, the silk cocoons production in Kashmir was merely 8.32 lakh kilograms in 2009 as compared to 15 lakh kilograms in 1960. The decrease can be well attributed to the substantial decline in the number of silk rearing farmers, turmoil and government monopoly and several other factors. According to figures available, Kashmir was the chief supplier to the state's silk industry by generating nearly two third of the total production; however, the political instability accentuated by militancy upturned the trend. Out of a total cocoon production of 10.36 lakh kilograms in 1988, Kashmir produced 6.65 lakh kilograms while the Jammu's share was only 3.71 lakh kilograms. As a matter of reality, currently, forty percent of the silk production comes from the Kashmir valley, while 60 percent comes from the Jammu region. As per a statement released recently by the apex cluster development service private limited, the diagnostic study has tried to identify the growth constraints of the cluster through direct interface with the cluster stakeholders and understanding cluster product, process and value chain of sericulture industry. It is worth mentioning that the rearing of cocoon crop runs for one month only, which starts from the first week of May. The short duration for rearing is also believed to be one of the reasons that caused disinterest among farmers. Over the decades, the sensitive industry of silk has suffered severe setbacks. Once considered to be one of the best revenue generating industries during the days of yore, the silk industry in Jammu \& Kashmir has almost perished (Bilal, 2010). Commissioner Secretary, Agriculture Production Department, has urged the Central Silk Board to formulate comprehensive projects in public private partnership (PPP) for the development of sericulture in Jammu and Kashmir by promoting quality mulberry leaf and cocoon production with special focus on value addition. He hoped that Central Silk Board will provide liberal funding to boost sericulture activities in the state, by way of suggesting policies and strategies for promotion and development of silk industry. Mulberry cocoons reared in the state of Jammu and Kashmir is of the most superior quality in Asia. It yields a very fine fiber that can be compared with the best in the world. For revival of silk industry, the sericulture department in association with Colleges, Universities, NGO's etc., must create massive awareness among various stake holders. The department has various schemes, such as Catalytic Development Programme (CDP), 
establishing silk reeling units, cocoon banks etc. These centrally sponsored schemes have lot of potential for reviving silk industry and need of the hour is to make people aware about the benefits of these schemes (Andrabi, 2017).

\section{References}

Afifa K. (2000) Principles of Temperate Sericulture. Kalyani Publications.

Andrabi S. D. A. (2017) Industrial Development: Socio-Economic Changes in Kashmir Society (1339-1551. A D.). American Research Journal of History and Culture, 3, pp.1-7.

Baqual M.F. (1995) Problems that hinder the growth of Sericulture in Jammu \& Kashmir State. Workshop on Development of Sericulture in Jammu \& Kashmir State, its future prospects, December 8 to 9, 1995.

Bhat T. A. (2014) An analysis of public private partnership (PPP) in Sericulture in Jammu \& Kashmir. Journal of Economics and Sustainable Development, 5:11.

Bilal A. S. (2010) Structural Changes in Jammu and Kashmir Economy, P.G. Department of Economics, University of Kashmir, pp. 1-94.

Dhar A., Farooq M. and Mir Nisar (2011) Recent Trends in Development of Bivoltine Sericulture in Jammu and Kashmir, Technical Compendium, Workshop held at SKICC, Srinagar, October, 29, 2011.

Directorate of Economics and Statistics (2017) Digest of Statistics, for different years, Govt. of J\&K state, pp. 1-2.

Economic Survey (2010-11)Directorate of Economics and Statistics, Govt. of Jammu and Kashmir.

Farhat I. Q. S., Malik M. A., Awquib Sabhat and Firdose Ahmad Malik (2010) "Adoption of Improved Sericulture Practices by
Sericulturists in Border Area of Kashmir", International Journal of Agricultural Statistics and Science, 6:1, pp. 197-201.

Ganie, N.A., Dar, K. A., Khan, I.L., Sharma, R.K. and Sahaf, K.A. (2018) Sericulture- A viable option for sustainable livelihood and employment generation for rural population of $\mathrm{J} \& \mathrm{~K}$. Global Journal of Bioscience and Biotechnology, ??(1): 200-203.

Hussain M. (2002) Geography of Jammu \&Kashmir, Rajesh Publications.

Kaneez F. (2018) Trends in cocoon and silk production in Jammu and Kashmir State-a case of concern. International Journal of Recent Scientific Research, 4(11): 18261830.

Nisar A. G., Afifa S. Kamili, Baqual M. F., Sharma R. K., Dar K.A. and Khan I. L. (2012) Indian Sericulture Industry with particular reference to Jammu \& Kashmir. International Journal of Advanced Biological Research, 2 (2): 194-202.

Nisar G.K. and Afifa K. (2012) Indian Sericulture Industry with particular reference to Jammu and Kashmir. International Journal of Advanced Biological Research, 2(2): 194202.

Qadri S. Farhat, Malik M.A., (2010) Sericultural Practices by Sericulturists in border area of Kashmir. Int. J. Agricult. Stat. Sci., 6(1):197201.

Singh H. and Andrabi R. H. (2015) Spatial Differentiation in Agricultural Development in Jammu and Kashmir: A Geographical Approach. International Journal of Scientific and Research Publications, 5(8): 1-9.

Tariq Ahmad Bhat (2014) An Analysis of Public Private Partnership in Sericulture in Jammu and Kashmir State (India). Journal of Economics and Sustainable Development, 5(11): 121-127.

\section{How to cite this article:}

Muzafar Ahmad Bhat, Zafar Iqbal Buhroo, Abdul Aziz, Jasmeena Qadir and Azam, M. 2020. An Overview of Current Scenario of Sericulture Industry in Jammu and Kashmir, India. Int.J.Curr.Microbiol.App.Sci. 9(06): 3813-3824. doi: https://doi.org/10.20546/ijcmas.2020.906.452 